\section{立体構造比較サーバMATRASの \\ 使い方}

奈良先端科学技術大学院大学情報科学研究科 川端 猛

\section{1. はじめに}

あるタンパク質と似ている他のタンパク質を探した いとき，まず最初に試みるべきはアミノ酸配列の相同 性検索であろう。しかし, 同じファミリーのタンパク 質の中でも, アミノ酸配列の一致度が低くなってくる と, 配列の類似性だけで議論するのには限界が出てく る。 そんな場合, 立体構造の情報を使うことを敃勧め する. 立体構造は進化的に保存性が高いため, より遠 縁の類似性の発見や正確なアラインメントが可能にな る. また，構造から機能部位が端的にわかる場合も多 いため, より分子機能を意識した考察を行うこともで きる. MATRASは, こうした立体構造比較が必要なと
きに役立つサーバである ${ }^{1)}{ }^{2)}($ Fig. 1). 他に類似のサー バとして DALI ${ }^{3)}, \mathrm{CE}^{4)}, \mathrm{VAST}^{5)}$ などがあり, 類似性ス コア, 比較アルゴリズム, WEBインターフェースにそ れぞれ特徴がある.

MATRASは,「マルコフ連鎖による構造変化モデルを 利用した相同性と相似性の対数オッズ関数」という特 殊なスコアを使って相同な構造類似性を認識するよう に設計されている.もちろん, 背景にある理論を一切 知らなくても MATRASサーバは動くわけで, 本稿では, WEBサーバの使い方と比較結果の見方を「実験技術」の 1つとしてマニュアル風に紹介することにする. 方法の 詳細を知りたい方はMATRASの原論文 ${ }^{1)}$,2) や筆者の「実 験医学」誌の総説の前半6) を参照していただきたい. ま た, タンパク質立体構造の類似性一般について関心が ある方は $\mathrm{SCOP}^{7)} や \mathrm{CATH}^{8)}$ などの構造分類データベー スをチェックしてみることを㘯䡃めする.

\section{アドレス}

http://biunit.naist.jp/matras

想定されるユーザー

(1)X 線結晶解析や NMR で新規の構造を決定し, 既 知構造との比較をしたい方

(2) あるファミリーの進化的な関係を, 広く遠縁のタ ンパク質まで含めて議論したい方

(3) 系統樹の作成や残基の保存を知るために, できる

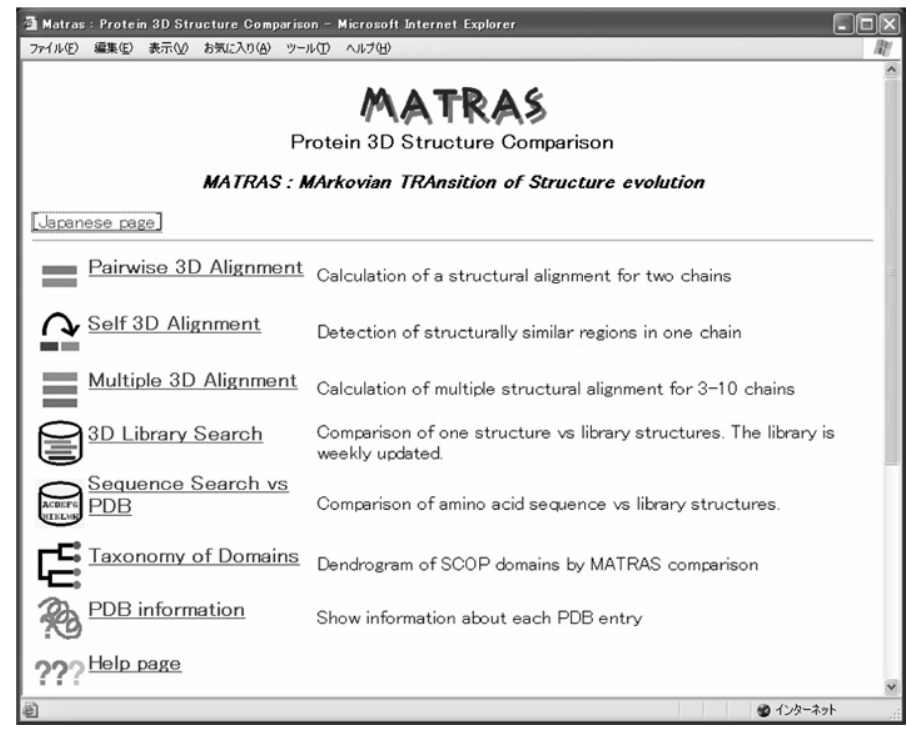

Fig. 1. A top page of MATRAS web server.

\title{
How to Use MATRAS Server?
}

Takeshi KAWABATA

Graduate School of Information Science, Nara Institute of Science and Technology 
だけ正確なアラインメントが必要な方

(4) 立体構造とアミノ酸配列の関係，あるいは立体構 造と機能との関係に興味がある方

\section{2. おもなサービス}

\section{1 ペアワイズ3Dアラインメント}

これは2つの構造をアラインメントする基本的な機 能であり, MATRAS サーバの機能はすべてこのぺアワ イズアラインメントをベースとして組み立てられてい る. 構造の入力法としては, PDBコードの入力, ユー ザーのローカルマシンからの PDB ファイルのアップ ロードの2 通りが選択できる. MATRAS はPDBファイ ルの中の 1 つの鎖を単位として比較を行うので, PDB コードに加えて，A とか $\mathrm{B}$ とかの鎖識別子（chain identifier）を入力する必要がある. 比較結果は, (1) 類 似性の情報, (2) アラインメント, (3) 重站合わされた 構造の 3 種類の情報が表示される.

Fig. 2 にプラストシアニン（PDBコード : 9pcy）とア ズリン（PDBコード : 4azu A 鎖) を比較した例を示す.

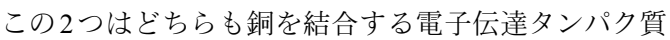
で, キュプレドキシンというスーパーファミリーに属 する. [SIMILARITY] の “Seq 17.0\%”という表示は配 列の同一残基率が $17 \%$ であること, “CRMS $4.33 \mathrm{~A} ”$ は 平均二乗誤差が $4.33 \AA$ であることを示す。 その下の行 の“Rdis”はMATRASのスコアが自分自身を比較した ときの值に比べてどのくらい充足しているかを百分率 で表した值である. 次の行の “[RELIABILITY] Superfamily 66.5\% Fold 93.9\%” は, この類似性スコア Rdis を もつ構造のペアが, SCOPの Superfamily あるいは Fold
が同じであると判定される確率である.これは事前に 行ったSCOPデータベース内の構造の総当り計算から見 積もっている. “[BEGIN ALIGNMENT]”のあとに残 基ごとのアラインメントが 2 次構造とともに表示され ている. この場合，ギャップがかなり多いが，銅に配 位結合する4つの機能残基 (プラストシアニンの His 37 , Cys84, His87, Met92）に対応するアズリンの残基のア ミノ酸種がきちんと保存されていることから, 正しそ うなアラインメントであることがわかる. また画面下 の “3D VIEW” は重ね合わせ構造を表示するためのリ ンクであり， 3 通りの方法が選べる。“ “[3D (image) $] ”$ は画像による表示である。これはプラグインを必要と しないが，回転等の操作はできない. Chime ${ }^{9)}$ という 構造を表示するプラグインをインストールしておけば, “[3D (Chime-plugin) ]”を選択すると， Fig. 2のような ボタン付きの表示が可能になる. また, UNIX系のマシ ンでは，しかるべき設定をすれば“[3D (rasmol)]”か ら $\mathrm{rasmol}^{10)}$ を外部アプリケーションとして起動して重 ね合わせ構造を表示することも可能である.

\section{2 マルチプル3Dアラインメント}

これは複数の立体構造をアラインメントする機能であ る. 構造の入力法としては同様にPDBのコードを入力 するか，ユーザーのローカルマシンから， PDBファイ ルをアップロードすることができる. 計算時間の都合か ら, 入力できる構造の数は 10 個に制限してある. Fig. 3 にプラストシアニン (9pcy-), アズリン (4azuA) に加 えて, シュードアズリン (8paz-) とアウラシアニン （1qhqA）を加えた計 4 つの構造のマルチプル 3D アラ インメントの例を示す.ペアワイズと同様にアラインメ

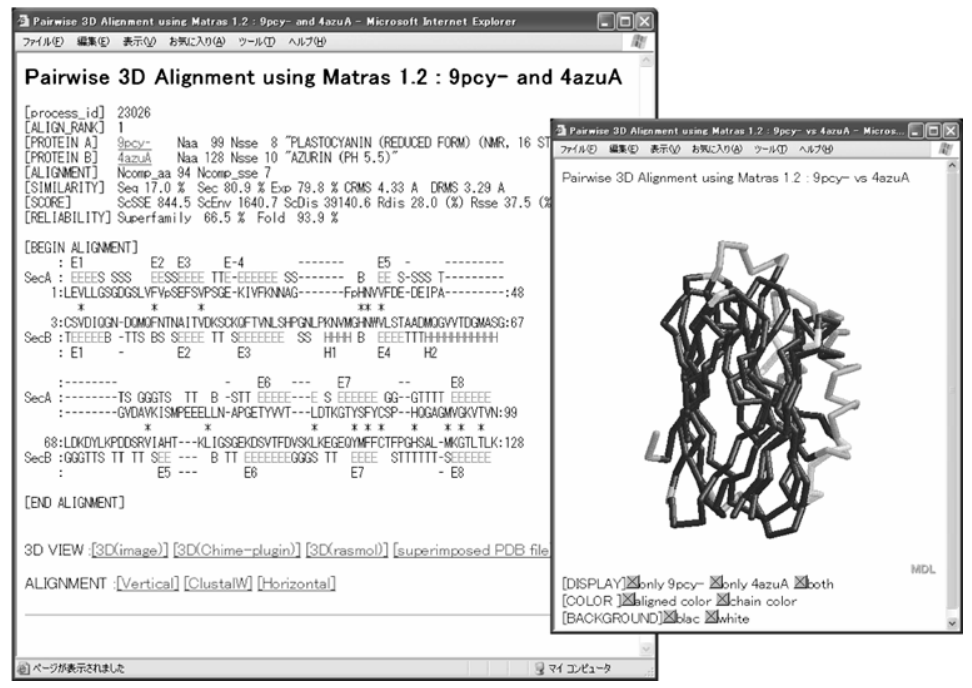

Fig. 2. Pages for pairwise 3D alignment. 


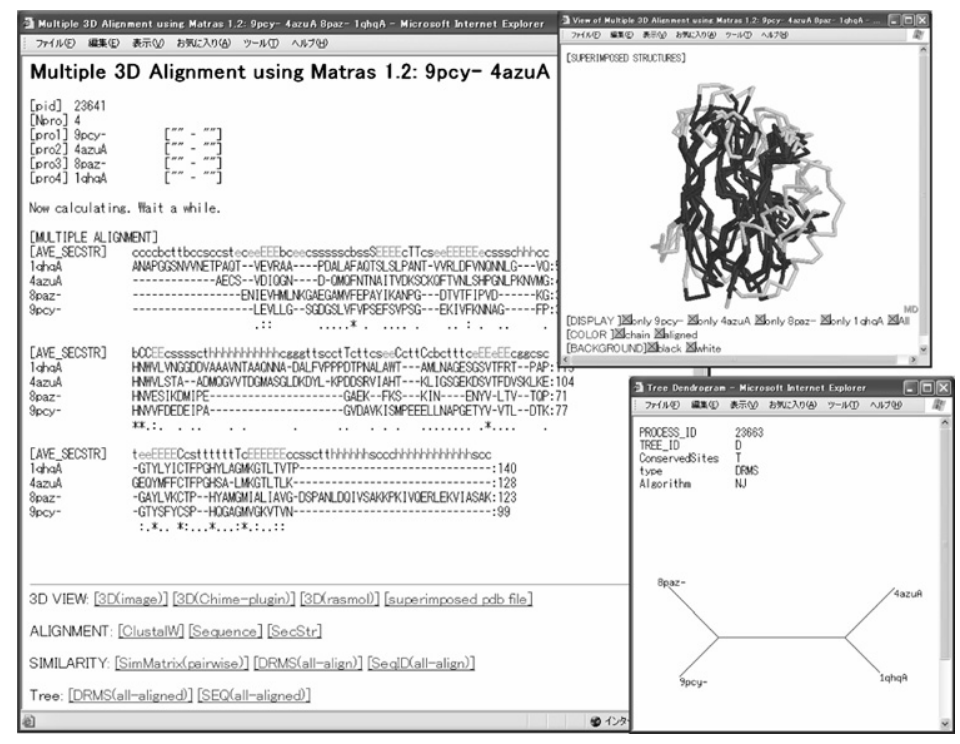

Fig. 3. Pages for multiple 3D alignment.

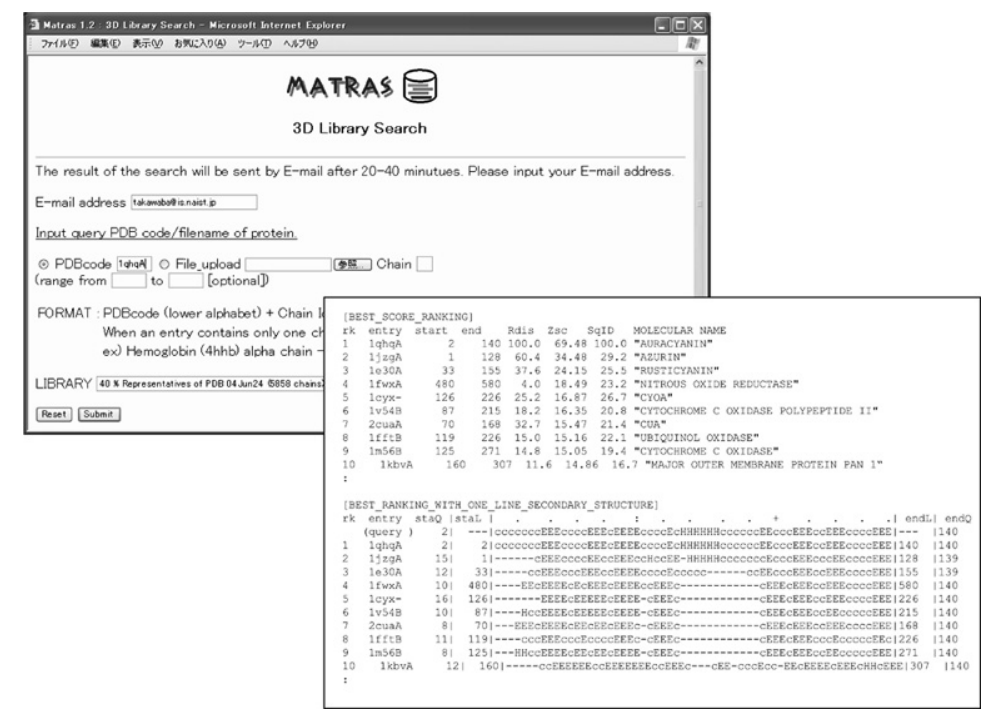

Fig. 4. Pages for 3D library search.

ントと重ね合わせ構造が表示される. また, 構造類似性 や配列類似性を樹形図として表示することもできる.

\subsection{Dライブラリ検索}

これは, 1つのクエリ構造に対して, 構造ライブラ リの中の類似構造検索を行うサービスである. 立体構 造版の BLAST ${ }^{11)}$ のようなものだ. このサービスは計算 時間の都合から, 結果を電子メールで返信する形式を とっている. 構造ライブラリとしては最新のPDBの代 表セットかSCOPの代表ドメインセットを選択するこ とができる. Fig. 4 にアウラシアニン（1qhqA）をクエ
リ構造として最新PDBの代表セットを構造ライブラリ にした場合の, 入力WEB画面と, 電子メールで送信さ れる結果の一部を示す。発見された類似構造が似てい る順にソートされて示されるほか, 1 構造 1 行のラフな 2 次構造アラインメント表示, それぞれのペアワイズア ラインメントなどの情報が含まれている.

\section{4 アミノ酸配列とPDBの配列相同性検索}

MATRASは原則的に立体構造どうしを比較するWEB サーバだが, ユーザーの要望に答えて, 配列と立体構 造を比較するサービスも行っている.これは, ユーザー 


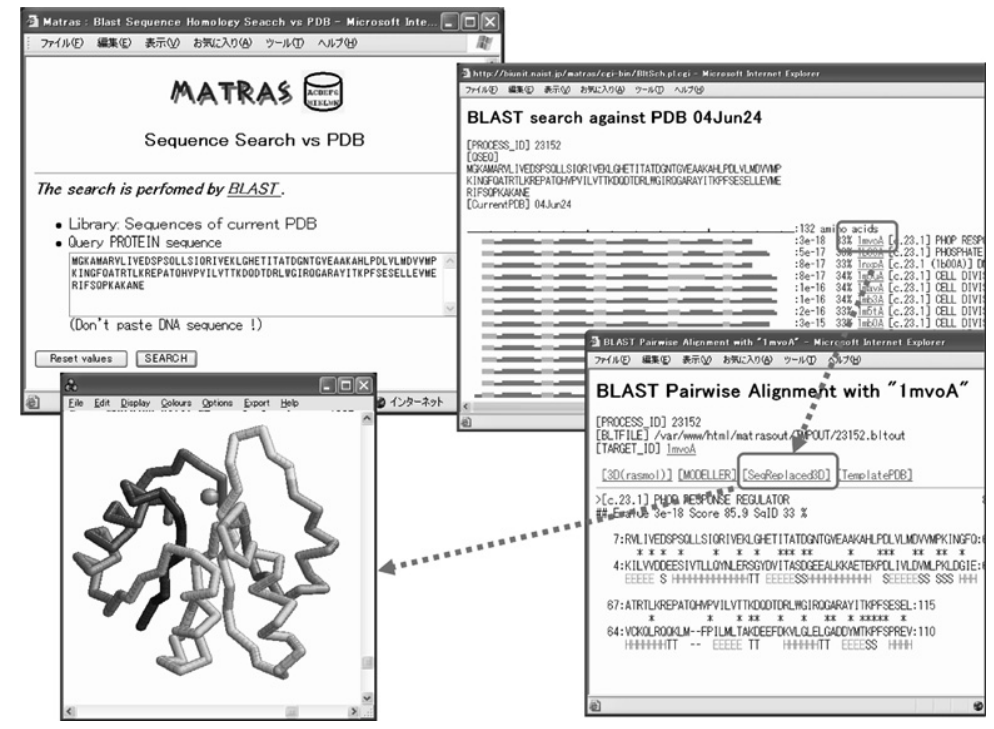

Fig. 5. Pages for sequence search vs PDB.

が入力したアミノ酸配列をクエリとして, 最新の PDB の配列データライブラリに対して, BLASTの配列相同 性検索をかけるサービスである. ただし, 単なる BLAST ではなく, 簡易な立体構造予測として使えるように, 本 来のBLAST の出力に構造からの情報を追加している.

Fig. 5 に例を示す。まず, クエリにアラインされたラ イブラリ内のタンパク質の 2 次構造がバーで表示され る.このページでPDBコードをクリックすると, ペア ワイズアラインメントが2次構造の情報付きで表示さ れる.上の “[MODELLER]” をクリックすると, ホ モロジーモデリングソフト MODELLER ${ }^{12)}$ 用の制御スク リプトファイルがBLASTのアラインメントを元に生成 される.ユーザーが既にMODELLERを自分の計算機に インストールしてあれば, これをカットアンドペース トするだけでモデリングの計算を開始することができ る. また, “[SeqReplaced 3D]”をクリックすると, 予 測立体構造のPDBファイルが表示される.これは, テ ンプレート構造の座標はそのままで, クエリのアミノ 酸配列と残基番号に書き直しただけの簡易モデリング 構造である．置換された側鎖原子や挿入された残基は 一切モデリングされていないので分子シミュレーショ ンには使えないが, アミノ酸の大体の空間配置を知る にはこれで十分であると思う。

\section{3. 最後に}

最近, 一般公開されている立体構造比較プログラム どうしを評価する論文が， 2 件発表された ${ }^{13)}{ }^{14)}$. どち らにおいても, MATRAS は最良とまではいかないまで
も, DALIなどの有名プログラムと十分比肩する性能だ とされている. 読者の皆さんで立体構造比較に関心の ある方はぜひ使っていただき，タンパク質の進化史や その機能の多様性の考察に役立てていただければと思 う.

\section{謝 辞}

このWEBサーバの開設・維持作業は, 文部科学省の 科学研究費特定領域研究「ゲノム情報科学」および科 学技術振興調整費新興分野人材養成プログラムによっ て支援を受けた。

\section{文 献}

1) Kawabata, T. and Nishikawa, K. (2000) Proteins 41, 108122.

2) Kawabata, T. (2003) Nucl. Acids Res. 31, 3367-3369.

3) http://www.ebi.ac.uk/dali/

4) http://cl.sdsc.edu/ce.html

5) http://www.ncbi.nlm.nih.gov/Structure/VAST/vast.shtml

6) 川端 猛 (2000) 実験医学 (増刊) 19,73-81.

7) http://scop.mrc-lmb.cam.ac.uk/scop/

8) http://www.biochem.ucl.ac.uk/bsm/cath/

9) http://www.mdlchime.com/products/framework/chime/ index.jsp

10) http://www.openrasmol.org

11) http://www.ncbi.nlm.nih.gov/BLAST/

12) http://www.salilab.org/modeller/modeller.html

13) Novotny, M., Madsen, D. and Kleywegt, G. J. (2004) Proteins 54, 260-270.

14) Sierk, M. L. and Pearson W. R. (2004) Protein Science 13, 773-785. 
川端 猛（かわばた たけし）

奈良先端科学技術大学院大学情報科学研究科客員助教授

連絡先： =630-0192 奈良県生駒市高山町 8916-5

E-mail: takawaba@is.naist.jp 